\title{
Contingent Faculty Perceptions of Organizational Support, Workplace Attitudes, and Teaching Evaluations at a Public Research University
}

\author{
Min Young Cha \\ University of Nebraska- \\ Lincoln, Lincoln, NE, USA
}

\author{
Carol Carrier \\ University of Minnesota, \\ Twin Cities, Minneapolis, MN, USA
}

\author{
mcha2@unl.edu
}

\section{carrier@umn.edu}

\begin{abstract}
This research examines contingent faculty's perception of organizational support, workplace attitudes, and Student Ratings of Teaching (SRT) in a large public research university to investigate their employee-organization relationship. According to t-tests and regression analyses for samples of 2,229 faculty and instructional staff who answered the survey and had SRT data (tenured and tenure-track faculty: $1,708,76.6 \%$ of total; contingent faculty: $521,23.4 \%$ of total), employment relationship of contingent faculty in this institution was closer to a combined economic and social exchange model than to a pure economic exchange model or underinvestment model. Contingent faculty's satisfaction with work, satisfaction with coworkers, perception of being supported at work, and affective organizational commitment were higher than tenured and tenure-track faculty at a statistically significant level. In addition, contingent faculty had higher SRT mean results in all areas of SRT items in medium-size (10-30) classes and in 'class presentation,' 'feedback,' 'deeper understanding,' and 'interest stimulated' in large-size (30-50) classes than Tenured and Tenure-track Faculty. These results not only refute the misconception that contingent faculty have too little time to provide students with feedback but also support that they provide students with good teaching, at least in medium-size and large-size classes. Whereas these results might be partially attributable to the relatively stable status of contingent faculty in this study (who work for more than 50 percent FTE), they indicate that, as a collective, contingent faculty also represent a significant contributor to the university, who are satisfied with their work, enjoy the community they are in, and are committed to their institution.
\end{abstract}

Keywords: contingent faculty, public research university, employee-organization relationship, perceived organizational support, workplace attitudes, student ratings of teaching

Material published as part of this publication, either on-line or in print, is copyrighted by the Informing Science Institute and Preeminent Leadership and Research Solutions, LLC. Permission to make digital or paper copy of part or all of these works for personal or classroom use is granted without fee provided that the copies are not made or distributed for profit or commercial advantage AND that copies 1) bear this notice in full and 2) give the full citation on the first page. It is permissible to abstract these works so long as credit is given. To copy in all other cases or to republish or to post on a server or to redistribute to lists requires specific permission and payment of a fee. Contact Publisher@InformingScience.org to request redistribution permission.

\section{Introduction}

Established in the late 19th century as full-time professionals after World War II, the quintessential type of professorate in higher education has been Tenured and Tenure-track Faculty (TTTF) (Brubacher \& Rudy, 1997; G. Rhoades, 1996). Such individuals were typically assigned to tripartite roles - advancing disciplinary knowledge, distributing this

Peer Blind Reviewed Research Article. Editor: Crystal Chambers

Submitted: December 2, 2015; Revised: February 15, 2016; Accepted: March 24, 2016 
knowledge in classrooms, and serving their academic disciplines and campus (Martin \& Berry, 1969). With secured status and academic freedom, the American faculty were central to the flourishing of higher education.

Nevertheless, traditional tenure-track hires, which include a six-year (or longer) probationary period followed by securing tenure with long-term job security, are increasingly complemented by various types of full-time or part-time, contract-based or "contingent" faculty appointments. Between 1975 and 2007, the percentage of full-time, non-tenure track faculty has doubled nationwide from 18.6 percent to 37.5 percent (Ehrenberg, 2010, October 1; Newfield, 2008). Further, nearly 60 percent of new full-time faculty appointments are now under temporary contracts. During the past three decades, the number of part-time faculty (who are mostly on non-tenure track appointments) has also more than tripled. The fact that the use of full-time and part-time, nontenure track faculty has become more common across many types of institutions is a sign of growing diversity of faculty work and appointment systems (Bataille \& Brown, 2006; Schuster \& Finkelstein, 2006).

With increasing specialization and division of faculty roles, faculty appointment systems have become more diverse as a result. Faculty are hired under a variety of appointment types, hiring procedures, salary ranges and promotion benefits (Bland, Center, Finstad, Risbey, \& Staples, 2006). Although the contingent faculty tracks were not the norm in the recruitment system of academia, especially in research universities, an increasing portion of research staff members are also hired on a contingent-faculty basis. This trend is more apparent when recruiting teaching faculty. Contingent faculty now constitute a substantial proportion of the teaching staff in higher education, regardless of the type of institution (Gappa \& Leslie, 1993; Kezar \& Sam, 2011). More than half of all professionals delivering instruction in higher education are non-tenure track contingent professionals (Schuster \& Finkelstein, 2006), who most often are heavily involved in undergraduate instruction (Baldwin \& Chronister, 2001; Baldwin \& Wawrzynski, 2011; Newfield, 2008; G. Rhoades, 2006).

Research on college student enrollment indicates that student perception of the faculty is the main factor contributing to their success (Hofman, Posteraro, \& Presz, 1994, May). According to Umbach and Wawrzynski (2005) study, students reported higher levels of engagement and learning at institutions where faculty interacted with, challenged, and valued their educational experiences. It is clear that faculty who are committed to students' learning are very important for quality education. Nevertheless, students' perceptions of contingent faculty's instruction have not been examined. In most campuses, a systematic understanding of contingent faculty's worklives and their employment relationship with organization - as viewed in their perception of organizational support, workplace attitudes, and work performance - has been absent (Harper, Baldwin, Gansneder, \& Chronister, 2001; Kezar \& Sam, 2011).

A growing number of studies have reported negative aspects of contingent faculty's worklives such as depression, anxiety, and stress at work due to their contingent employment status as well as a negative impact on student outcomes, such as a lower graduation rate (Ehrenberg \& Zhang, 2005; Jacoby, 2006), a lower transfer rate (Eagan \& Jaeger, 2009; Jaeger, 2008; Jaeger \& Eagan, 2011b), and a lower retention rate (Jaeger \& Eagan, $2011 \mathrm{a}$; Ronco \& Cahill, 2006). The proportion of contingent faculty was negatively associated with students' non-class-related interaction with them (Umbach, 2008, Nov).

On the other hand, another line of research suggested that the influences of contingent faculty were not always negative. Cox, McIntosh, Terenzini, Reason, and Quaye (2010) reported that contingent faculty had as much as or even more interaction with students outside of class sessions, compared to TTTF. According to Eagan and Jaeger (2008), while students were negatively affected by part-time faculty, neither having graduate teaching assistants nor full-time, non-tenure 
track faculty as their instructors was negatively associated with persistence into the second year. Lastly, a study of freshmen at a private research university in the Midwest found that students, particularly those who are average or are less-qualified, learned relatively more in their introductory courses from non-tenure track faculty than from TTTF, across a variety of subject areas (Figlio, Schapiro, \& Soter, 2013, September 1).

\section{Contingent Faculty at Public Research Universities}

Representing approximately 12 percent of America's higher education institutions, public universities have been central to the prosperity of the American higher education system. They enroll 35 percent of the nation's students and hire approximately half of all faculty (Gumport, 1997). In particular, since the industrialization and urbanization in the late 1880s and early 1900s, public research universities have made remarkable contributions to the American society (Lee, Cheslock, Maldonado-Maldonado, \& Rhoades, 2005). One of their most significant contributions, for example, has been the education of a large number of science and engineering undergraduates needed in the workforce (Brint, 2006). While prestigious, private universities attract and educate only a small number of students, large public research universities produce research studies and $\mathrm{Ph} . \mathrm{D}$. graduates in a greater quantity and provide a larger population of undergraduates with exposure to research experiences (Cross \& Goldenberg, 2009). According to Newfield (2008), public research universities in the United States have supported the notion that quality in teaching and research and equality in access can be achieved at the same time and can reinforce each other. Due to state subsidies, such institutions have offered a more affordable cost option for students compared to private institutions.

At the same time, currently the public appears concerned about faculty's commitment to undergraduate education at large public research universities, given the heightened demands for faculty's time and attention to graduate students and research activities (Altbach, 2005; El-Khawas, 1992). While the impact of undergraduates' involvement in research experiences at these institutions has been largely left unheralded (Cross \& Goldenberg, 2009), the public demands that higher education institutions should be more transparent, accountable, and outcome-driven for both what is taught and how students learn (Hearn, Lewis, Kallsen, Holdsworth, \& Hones, 2006; Heck, Johnsrud, \& Rosser, 2000; Lee et al., 2005; Rachelle, 2005). With such expectations, understanding the contributions of contingent faculty at public research universities becomes ever more important because of contingent faculty's growth in those institutions (Cross \& Goldenberg, 2009).

Research universities have not paid as much attention to their non-traditional faculty as other types of institutions that have a longer history of employing contingents as a substantial part of instructional staff. For example, the proportion of part-time faculty is still relatively smaller (14.4 percent) in public research universities than in other types of higher education institutions. The proportion of full-time contingent faculty is, however, the highest in the doctoral research institutions (Bland et al., 2006).

What distinguishes today's contingent faculty in higher education from contingent workers in other industries is the requirement of extensive graduate training for advanced degrees, for example, Ph. D., and other professional identities (Kezar \& Sam, 2011). Furthermore, contingent faculty directly interact with students, through their instruction, whereas contingent employees in other industries are typically not as engaged with their service recipients (Cross \& Goldenberg, 2009). In spite of these distinctive characteristics, however, knowledge about academic employees with non-traditional, contingent status have not substantially informed the human resources policies of higher education. Given the increasing presence of contingent faculty in the primary role of teaching, understanding how they perceive their worklives and are perceived by their students in classrooms is essential for ensuring successful achievement of an institution's educational mission. 
The expansion of non-tenure track faculty, particularly those working full-time on a contract basis, was noticeable from 1980s in the institution where this study is based. Although their appointments are officially not permanent but annually renewable, these employees tended to work for the university over a long period of time. Their compensation plans were separate from those of TTTF, but some benefits including retirement plans were shared with TTTF. They were also represented in university governance structures such as faculty consultative committees and university senates (Tkachenko \& Seashore, 2013, Nov).

To address the gap in the knowledge on contingent faculty's employment relationship with their public research university employer and how students perceive instruction delivered by contingent faculty, as evaluated in Student Ratings of Teaching (SRT), this study first examined the perceptions of workplace support and workplace attitudes of contingent faculty in comparison with TTTF. Secondly, how demographic, attitudinal, and organizational factors explain workplace attitudes such as overall job satisfaction and affective organizational commitment of contingent faculty was analyzed. The analysis of the same variables for TTTF was also conducted to understand any difference in these groups. Lastly, SRT results were compared between contingent faculty and TTTF to investigate students' perception of their teaching. The analysis is limited to the case of one public research university in the Midwest where the data were collected. Contingent faculty in this study include both contract-based non-tenure track faculty holding professorial titles and instructional staff without professorial titles who are employed at the university.

The following research questions were asked:

1) Do contingent faculty and TTTF hold different attitudes about the workplace?

2) Do contingent faculty and TTTF hold different perceptions about organizational support?

3) What factors significantly relate to the overall satisfaction of contingent faculty and TTTF?

4) What factors significantly relate to the affective organizational commitment of contingent faculty and TTTF?

5) Are there differences in how students evaluate the teaching of contingent faculty and TTTF?

\section{Conceptual Framework}

In this section, a conceptual framework to understand worklives and employment relationship of contingent faculty is presented, followed by explanations of the concepts contained in the framework. Based on the conceptual framework, this study examines the relationships among the following constructs: perception of organizational support, job satisfaction, and overall satisfaction and organizational commitment. SRT was used as an indicator of students' satisfaction with teaching to understand contingent faculty's performance in classrooms.

\section{Social Exchange Theory}

March and Simon (1993) stated that exchange between organizations and employees refers to inducements provided by organizations in return for what employees contribute. Based on this understanding, social exchange theory offers a perspective to understand the social aspects of human relations that are "distinguished from strictly economic exchange by the unspecified obligations incurred in and the trust both required for and promoted by it" (Blau, 1964, p.8). It serves as "a framework for understanding the EOR (Employee-Organization Relationship)" (Shore \& Coyle-Shapiro, 2003, p. 443).

Providing a framework to understand employees' organizational behaviors, social exchange theory stresses the importance of employees' motivation to achieve organizational goals (Aselage \& 
Eisenberger, 2003). Unlike economic transactions, social exchange refers to the voluntary actions of individuals who are motivated by the indefinite returns such actions are expected to induce. It entails unspecified, broad, open-ended obligations on the part of both employer and employee (Blau, 1964) and requires that relationships pursuing reciprocal commitment be established on trust.

Based on balance and the content of the exchange, types of EOR can be categorized as 1) quasispot contract (pure economic exchange), 2) mutual investment (combined economic and social exchange model), 3) underinvestment, and 4) overinvestment (see Table 1) (Tsui, Pearce, Porter, $\&$ Tripoli, 1997). Balanced exchanges indicate that the obligations of each party are at the same level, whereas obligations of each party are not at the same in unbalanced exchanges. Pure economic exchange and combined economic and social exchange models are examples of balanced exchanges, and examples of unbalanced exchanges include underinvestment and overinvestment.

Table 1. Types of Employee-Organization Relationship (EOR)

\begin{tabular}{|c|c|c|c|c|}
\hline Approaches & \multicolumn{4}{|c|}{ Types } \\
\hline \multirow[t]{2}{*}{$\begin{array}{l}\text { A. Balanced } \\
\text { exchange }\end{array}$} & $\begin{array}{l}\text { A-1. } \\
\text { A pure eco- } \\
\text { nomic ex- } \\
\text { change model } \\
\text { (quasi-spot } \\
\text { contract) }\end{array}$ & $\begin{array}{l}\text { free to hire and } \\
\text { fire workers } \\
\text { - market-like flexi- } \\
\text { bility } \\
\text { - employer offers } \\
\text { short-term, purely } \\
\text { economic in- } \\
\text { ducements in ex- } \\
\text { change for well- } \\
\text { specified contribu- } \\
\text { tions by the em- } \\
\text { ployee } \\
\text { neither party has } \\
\text { an obligation to } \\
\text { maintain a long- } \\
\text { term relationship } \\
\text { appropriate when } \\
\text { a performance } \\
\text { contribution can } \\
\text { be clearly defined } \\
\text { and measured }\end{array}$ & $\begin{array}{l}\text { A- } 2 \text {. } \\
\text { A combined } \\
\text { economic and } \\
\text { social ex- } \\
\text { change model } \\
\text { (mutual in- } \\
\text { vestment) }\end{array}$ & $\begin{array}{l}\text { - develops and encour- } \\
\text { ages employees to } \\
\text { adopt expandable work } \\
\text { roles } \\
\text { - offers some degree of } \\
\text { employment security } \\
\text { - a clan-like flexibility } \\
\text { - employees' obligations } \\
\text { and contributions may } \\
\text { include jobs that fall } \\
\text { outside of prior agree- } \\
\text { ments or expertise } \\
\text { - employees are ex- } \\
\text { pected to learn firm- } \\
\text { specific skills and will- } \\
\text { ing to consider organi- } \\
\text { zation's interests as } \\
\text { important as their core } \\
\text { job duties }\end{array}$ \\
\hline & $\begin{array}{l}\text { - Obligatio } \\
\text { ended. } \\
\text { - Obligatio }\end{array}$ & $\begin{array}{l}\text { of each party are either } \\
\text { of each party are match }\end{array}$ & ed. & ied or broad and open- \\
\hline $\begin{array}{l}\text { B. Unbalanced } \\
\text { exchange }\end{array}$ & $\begin{array}{l}\text { B-1. } \\
\text { Under- } \\
\text { investment }\end{array}$ & $\begin{array}{l}\text { employer desires } \\
\text { flexible and expand- } \\
\text { able work behavior } \\
\text { by employees but at- } \\
\text { tempts to retain flex- } \\
\text { ibility to hire and } \\
\text { fire immediately }\end{array}$ & $\begin{array}{l}\text { B-2. } \\
\text { Over- } \\
\text { investment }\end{array}$ & $\begin{array}{l}\text { - employer provides } \\
\text { relatively high em- } \\
\text { ployment security to } \\
\text { employees but ex- } \\
\text { pects only narrowly } \\
\text { specified role behav- } \\
\text { ior in exchange }\end{array}$ \\
\hline
\end{tabular}

- Obligations of each party are not matched. 


\section{Constructs}

Four constructs were used in this study to examine employment relationship of contingent faculty in a large land-grant public research university. These include perception of organizational support, organizational commitment, job satisfaction, and students' satisfaction with teaching as evaluated by their ratings of faculty's teaching (SRTs).

\section{Perceived Organizational Support}

Among the major concepts derived from social exchange framework-Perceived Organizational Support (POS), Psychological Contract Theory (PCT), and Leader-Member Exchange (LME)-, POS offers an elaborated view on the exchange between employees and their employers by indicating the extent to which employees perceive provision of work conditions as intentional considerations and allocation of resources from their organizations (Eisenberger, Huntington, Hutchinson, \& Sowa, 1986). In order to expect mutual commitment from employees, support from the organization needs to be perceived as discretionary actions that were purposefully made regardless of circumstantial influences (Eisenberger, Jones, Aselage, \& Sucharski, 2004). If they perceive the support as unplanned or not deliberate, the same degree of credit is not given.

POS serves as an important socio-emotional indicator in the employment relationship. It is significantly related to positive outcomes, both at the individual (e.g., job satisfaction and positive mood at work) and the organizational levels (e.g., affective commitment, performance, and decreased withdrawal behavior). Employees who were well treated by their organizations were more likely to be affectively committed to them, show better performance, and are less likely to quit their jobs (Meyer \& Allen, 1984; Mowday, Porter, \& Steers, 1982). Increased POS induces more commitment to employers and their priorities, helping the organizations reach their goals (Eisenberger et al., 1986).

Johnsrud and Rosser (2002) and Rosser (2004) reported that faculty's perceptions of their worklives - including rewards, benefits, administrative relations, and organizational support - had direct impact on faculty members' morale and potentially on their intentions to leave. According to a study on women and minority faculty in a research-intensive university (Olsen, Maple, \& Stage, 1995), factors such as perceived institutional support, relationship with department, and work context were more predictive of job satisfaction than what their contract officially stated. It was also found that part-time contingent faculty's workplace satisfaction was significantly correlated with their perception of resources provided by the institution and respect (Eagan, Jaeger, \& Grantham, 2015). Lastly, Ambrose, Huston, and Norman (2005) noted in their single-institution interview study that even faculty who were successful achievers in their research, publications, and professional presentations may not feel supported by their colleagues and their institution.

As ineligibility to hold tenure implies, contingent faculty have been often identified with those who have insufficient organizational support and are faced with inequality. According to a survey conducted at a large university in a Mid-Atlantic state, the level of POS was lower for contingent faculty than TTTF (Wyatt-Nichol, 2007). Umbach (2008, Nov) also found, using social exchange and psychological contract theory, that part-time faculty were less committed to teaching and spent less time in advising students due to the lack of support from their organization. A focus group study in a public research university in the South indicated that contingent faculty experienced unfavorable work conditions such as lower salaries, lack of eligibility for employee benefits, inconsistent assignments and titles, lack of job security, unclear expectations for performance evaluations, lack of adequate office space and other resources, detachment from departmental and institutional governing bodies, and feelings of being undervalued by the unit to which they report as well as by the institution overall (Bataille \& Brown, 2006). Although contingent faculty increasingly contribute to the teaching mission of universities, they were often neither as signifi- 
cantly involved in governance as TTTF nor given professional development opportunities that include "all the activities designed to improve faculty performance in all aspects of their professional lives" (Nelsen, 1983, p. 70).

\section{Organizational Commitment}

Organizational commitment and job satisfaction have been of much interest and were widely researched in workplace psychology. Whereas job satisfaction is defined as one's attitude toward certain aspects of his or her job, organizational commitment is a broader concept that indicates the degree of an employee's overall affective attachment to his or her employing organization (Mowday \& Steers, 1979). It is defined as "a state of affairs where individuals are strongly attracted to (committed to) the goals, values, and objectives of their employer" (Steers, 1977, p. $115)$.

According to Meyer and Allen (1997) three-component model, components of organizational commitment consist of (1) affective commitment (emotional attachment to organization), (2) normative commitment (belief in or loyalty to employer), and (3) continuance commitment (perceived cost of leaving). As organizational commitment is based on a reciprocal exchange relationship between individuals and organizations, an employee's commitment is highly related to his or her perception of organization's commitment to the employees (Eisenberger et al., 1986). Organizational commitment is positively related to both individual and organizational outcomes such as job satisfaction, job performance (Mathieu \& Zajac, 1990), lower intention to leave and turnover, and organizational effectiveness (Meyer \& Herscovitch, 2001).

Disciplines and seniority are significant factors in understanding faculty's organizational commitment. According to a study from a stratified random sample of 40 research universities, Neumann and Finaly-Neumann (1990) found that faculty's commitment to their universities was dependent on their disciplinary fields and career stages. While reward was a strong predictor for faculty's commitment in the hard sciences, social support (e.g., emotional concern, information, and appraisal) was a more important predictor for those in the soft sciences. Commitment to the university was the highest among senior faculty members whereas no difference was found between faculty members in their early-career and mid-career stages.

Organizational commitment has been one of the most frequently researched topics related to contingent work, with regard to whether contingent employees were more or less committed to their organizations than their permanent counterparts (Connelly \& Gallagher, 2004; Coyle-Shapiro \& Kessler, 2000; McDonald \& Makin, 2000; Pearce, 1993; Van Dyne \& Ang, 1998). According to studies, the level of organizational commitment of contingent employees varied: lower than permanent employees (Coyle-Shapiro \& Kessler, 2000; Van Dyne \& Ang, 1998), higher (McDonald $\&$ Makin, 2000) or equal to them (Pearce, 1993). These mixed results suggest that several personal, organizational factors were related to their commitment (Coyle-Shapiro \& Kessler, 2002). For example, contingent employees showed more commitment and engagement when they were treated fairly and when appropriate organizational support was provided (Liden, Wayne, Kraimer, \& Sparrowe, 2003).

\section{Job Satisfaction}

As one of the major indicators of organizational effectiveness (Cameron, 1978) and productivity (Likert, 1961, 1967; Mayo, 1963; McGregor, 1960), job satisfaction refers to "pleasurable, emotional state resulting from the appraisal of one's job as achieving or facilitating the achievement of one's job values" (Locke, 1969, p. 364). Kalleberg (1977) identified six different dimensions of job satisfaction in intrinsic and extrinsic realms. Intrinsic dimensions include the degree to which the work task itself is interesting and motivating. Extrinsic dimensions refer to other work- 
related conditions such as financial reward, career opportunities, autonomy and convenience related to work, relationships with other colleagues, and resources available to employees.

Though a consistent causal relationship is not always definite, a significant, positive relationship exists between job satisfaction and productivity (Cherrington, Reitz, \& Scott, 1971; Groves, Kahalas, \& Lamb, 1976; Wanous, 1974). Research indicates that higher satisfaction tends to result in higher organizational productivity (Katzell, Yankelovich, Fein, Ornati, \& Nash, 1975; Voorde, Veldhoven, \& Paauwe, 2009). Satisfaction also influences variables closely related to performance such as job withdrawal (Hulin, 1991) and organizational commitment (Mottaz, 1987).

Gender, ethnicity, career stages, ranks, and union status were important factors in understanding faculty satisfaction. For example, gender and ethnicity have been consistently reported as influential in faculty's perception of job satisfaction (Olsen et al., 1995; Rosser, 2004). Women faculty were less satisfied with their salary, benefits, and overall job, regardless of their part-time or fulltime status (Seifert \& Umbach, 2008; Toutkoushian \& Bellas, 2003). Part-time women faculty, in particular, reported lower satisfaction with their advancement opportunities, job security, and salary than male counterparts (Toutkoushian \& Bellas, 2003).

Career stage is one of the significant factors in contingent faculty satisfaction. Using a mixedmethod approach, D. C. Feldman and Turnley (2001) found that contingent faculty who were in their late career stages tended to be more satisfied with their jobs, committed to their professions, and engaged in behavior beneficial for the institution. There was no significant difference in their in-role performance depending on career stage.

Research indicates the relationships among workplace attitudes and performance are not as close among temporary employees, who frequently change their jobs and maintain their contingent status, as among permanent employees (Marler, Barringer, \& Milkovich, 2002). Controlling for demographic variables, part-time workers were likely to have lower satisfaction than full-time employees although some attitudes were reported to be higher depending on organizational structures, policies, reward systems, and the level of trust among the organization's members (Eberhardt \& Shani, 1984). Little has been known about how their personal motivation to work in contingent status impacts their job attitudes and performance (Connelly \& Gallagher, 2004). Contingent faculty's worklives have been also mostly understood from a deficit model, assuming that their low pay or lack of job security would be negatively related to teaching performance or other professional duties (Kezar \& Sam, 2011). Their perceptions of support at work and teaching effectiveness have not been understood, together with their workplace attitudes, in a holistic view of their worklives.

\section{Student Ratings of Teaching (SRT)}

Teaching is the primary role that a majority of contingent faculty members perform. It is, therefore, vital to examine how contingent faculty's teaching performances are viewed by students. Although students' ratings of teaching data have been often underutilized, monitoring the teaching evaluation data of contingent faculty could suggest some dependable guidance and evidence for supportive policies for their teaching.

According to Seldin $(1984,1988)$, sources of measuring teaching performance include multiple options such as classroom observation, analysis of audio or videos of classes, self-evaluation, review of instructional materials, long-term follow-up of student performance, alumni opinions, and students' future enrollments in elective courses. Among these options, SRT - which started as a private form of evaluation between students and teachers in classrooms - has become one of the most commonly used methods to assess students' satisfaction with the quality of teaching (Cohen, 1981; K. A. Feldman, 1988; Marsh, 1984, 1987; Seldin, 1993). Student evaluations of teaching 
have multiple labels, including these: Teacher Ratings Forms (TRFs), Teacher Course Evaluations (TCEs), Student Ratings of Teaching Effectiveness (SRTEs), or Student Ratings of Instructions (SRIs). Regardless of label, such measures are extensively used in higher education institutions in North America as well as around the world (Abrami, Theall, \& Mets, 2001; Seldin, 1993). SRT has grown into a public means of communication - particularly in large institutionsto inform students of classes and teachers, to give feedback to teachers on their classroom performance for improvement, and to influence further decisions on their employment status and programs (CommitteeOnUndergraduateTeaching, 1968).

Over time, student evaluation of teaching has matured in its methodological rigor to provide administrators and faculty members with distinct information regarding the quality of faculty teaching and some aspects of student learning. For example, Cohen (1987) reported statistically significant mean correlations, between students' achievement and components of student evaluation of teaching, from .55 for instruction structure to .45 for overall instructor score. Some multi-section validity studies have also indicated considerable correlation between student ratings of teaching and student achievement as measured by examination performance (Abrami, d'Apollonia, \& Cohen, 1990; d'Apollonia \& Abrami, 1997). Researchers generally agree that student evaluation results acceptably, although not perfectly, affirm the results of the four most commonly used measures of teaching effectiveness - student learning, student comments, alumni ratings, and outsider observations of teaching (Kulik, 2001).

Demographic characteristics of students, such as age, sex, grade, and veteran status, were found to make little difference in their rating results. However, graduate students tended to rate their teachers higher than undergraduates (Remmers, 1930; Remmers \& Elliot, 1949). Instructors who do not hold M.A. or Ph.D. were rated lower than those who do, and older instructors tended to be rated lower than younger teachers (Riley, Ryan, \& Lifshitz, 1950). In regards to class characteristics, there were both results that class size and required/elective status were not correlated with student ratings (Goodhartz, 1948; Marsh, 1987) or negatively correlated.

According to Theall and Franklin (2001), certain conditions such as being large, required, and out-of-major courses may contribute to lower ratings, compared to the conditions of being elective, upper-level, and in-major courses. This does not necessarily mean that teaching qualities were lower in former conditions but that these conditions may make accomplishment of effective teaching and learning more difficult. For a sensible use of student evaluation data, therefore, characteristics such as class size, disciplinary contexts, and electivity would need to be considered as well (K. A. Feldman, 1978).

Some aspects of teaching-related behaviors of contingent faculty have been also examined by researchers. For example, Johnson (2011) found that contingent faculty tended to give higher grades, which may lower students' motivation for hard work. A study on contingent faculty's teaching practices revealed that, whereas part-time contingent faculty's teaching practices were somewhat different, full-time contingent faculty had teaching practices similar to those of TTTF, such as assigning term/research papers and requiring multiple drafts of written work and oral presentations (Baldwin \& Wawrzynski, 2011).

\section{Method}

The purpose of this study was to understand the perceptions of organizational support and workplace attitudes of contingent faculty and to examine their student ratings of teaching in comparison with those of TTTF. The results were examined using data from three iterations of a biennial employee survey and teaching evaluation data at a large land-grant public research university in the Midwest. Descriptions of participants, survey instruments, and procedures are presented below. 


\section{Participants}

The participants of this study are faculty and instructional staff who responded to the institutional worklife surveys in 2008, 2010, or 2012 at the central campus of a large public research university with very high research activity. The survey was distributed to employees at or over 50 percent FTE since 2004 every two years to have an understanding of employees' worklives. Although the primary interest group of this study is contingent faculty who have their students' ratings of teaching data, TTTF were also included as a comparison group. In this study, contingent faculty refer to both term faculty and instructional staff who are not on tenure-track.

Over the past few decades, the institution adopted a personnel system that allowed each college to make a decision of its instructional staffing ratio in categories as follows: 1) regular faculty (tenured and tenure-track faculty), 2) term faculty (contract, temporary and visiting), 3) term faculty (adjunct or clinical), 4) instructional academic professional staff, and 5) graduate teaching assistants. Term faculty refer to a group of researchers and professors who are not on the tenure-track. Their contracts are renewed yearly or for multiple years. Their roles may not be limited to only teaching and may include research depending on what their contracts require, but they are increasingly hired for teaching these days. The titles for term faculty include 1) Contract Faculty (e.g., Assistant Professor, Associate Professor, Professor, Teaching Assistant Professor, Teaching Associate Professor, and Clinical Assistant Professor), 2) Adjunct Professor (e.g., Adjunct Assistant Professor, Adjunct Associate Professor, Adjunct Professor, and Adjunct Instructor), 3) Instructor, and 4) Research Professor/Fellow. According to Carrier and Wilhelmson (2013), this group of professionals were called 'term faculty' in order to distinguish them from TTTF and instructional staff in the institution where this study is based.

Instructional academic professional staff members refer to employees whose primary roles are teaching students. Their contracts are renewed annually or on a multiple-year basis. The job titles for instructional staff include 1) Teaching specialist/Senior Teaching Specialist, 2) Lecturer/Senior Lecturer/Lecturer, and 3) Research Associate/Specialists. Graduate teaching assistants were not included in this study because their teaching experiences are often regarded as part of their graduate education. The best way to distinguish term faculty from instructional staff is whether they hold a professorial title or not in the university's data management system.

Such strategy enabled the institution to meet various instructional needs with flexibility. However, by policy, the proportion of non-TTTF was restricted to below 25 percent of the number of TTTF although exceptions were allowed when an additional supplemental plan was submitted by college. This collegiate personnel plan was monitored by the Provost's office and a major faculty committee, allowing room for flexibility while maintaining accountability (Carrier \& Wilhelmson, 2013).

Out of 6,300 faculty and instructional staff who were invited to the survey-in 2008, 2010, and 2012 - and had SRT data, a total of 2,229 (35.4\%) answered the survey (see Table 2). The majority of respondents were TTTF ( $\mathrm{n}=1,708,76.6 \%$ of the total faculty) and slightly less than a quarter of them ( $\mathrm{n}=521,23.4 \%$ of the total faculty) were contingent faculty. Demographic characteristics, such as gender and ethnicity, were compared with the original population to ensure that the responded group adequately represented the population. 
Table 2: Response rate by year

\begin{tabular}{lccrrrr}
\hline & \multicolumn{2}{c}{ TTTF } & \multicolumn{2}{c}{ Contingent Faculty } & \multicolumn{2}{c}{ All } \\
\cline { 2 - 7 } & Total & $\begin{array}{c}\text { n (\% within } \\
\text { TTTF })\end{array}$ & Total & $\begin{array}{c}\text { n (\% within } \\
\text { contingent FA) }\end{array}$ & Total & $\begin{array}{c}\text { N (\% within } \\
\text { all FA) }\end{array}$ \\
\hline 2008 & 1,352 & $578(42.8 \%)$ & 383 & $116(30.3 \%)$ & 1,735 & $694(40.0 \%)$ \\
2010 & 1,485 & $602(40.5 \%)$ & 770 & $185(24.0 \%)$ & 2,255 & $787(34.9 \%)$ \\
2012 & 1,449 & $528(36.4 \%)$ & 861 & $227(26.4 \%)$ & 2,310 & $755(32.7 \%)$ \\
Total & 4,286 & $1,708(39.9 \%)$ & 2,014 & $521(25.9 \%)$ & $\mathbf{6 , 3 0 0}$ & $\mathbf{2 , 2 2 9 ( 3 5 . 4 \% )}$ \\
\hline
\end{tabular}

\section{Instrumentation}

The main objectives of the institution-wide survey used in this study were to periodically collect data on the perceptions and attitudes of faculty and staff in their workplaces and to allow improvement of their work experiences through institutional and college level reporting. The questionnaire, developed by administrators and faculty members at the institution's management school, originally consists of over 70 questions asking various aspects of workplace - such as workplace attitudes, perceptions about the institution and its leadership and practices as well as work-life balance and personal well-being. For this study, only survey data from 2008 through 2012 were selected because of consistency in the questionnaire format and wording. Scales included in this study are as below.

\section{Perception of organizational support}

Organizational support by supervisors was measured using existing scales introduced by Greenhaus, Parasuraman, and Wormley (1990). The eleven items about supervisory support include sentences such as "My department chair or responsible administrator takes the time to learn about my career goals and aspirations," "... makes sure I get the credit when I accomplish something substantial on the job," and "...gives me helpful feedback about my performance." Since items adopted from Survey of Perceived Organizational Support (SPOS) (Eisenberger et al., 1986; Eisenberger et al., 2004; L. Rhoades \& Eisenberger, 2002) were not asked of faculty but of staff only, perceptions of support at work setting for faculty and instructional staff were measured using items asking to what extent they perceived that they were supported at work, which consisted of 13 items such as "In my current work setting, I am supported in efforts to be innovative," "to perform high quality work," "recognized for achievement," and "rewarded for achievement." Perceptions of organizational support and supervisory support were both measured with a five-point scale where five is strongly agree ( $5=$ strongly agree to $1=$ strongly disagree). The internal reliability for items of organizational support and supervisory support was each .94 and .95 .

\section{Workplace attitudes}

For measurement of job satisfaction, Job Descriptive Index (JDI) (Smith, Kendall, \& Hulin, 1969) was used to examine employees' satisfaction with work, coworkers, and supervisor/responsible administrator. Each category was assessed with five items that describe the conditions (satisfying or challenging) or characteristics (helpful, intelligent, or responsible) with the answer options of "Yes, Not sure, or No" in agreement or disagreement to them (see Table 3). Satisfaction with pay and benefits was measured with a five-point scale from the Pay Satisfaction Questionnaire developed by Heneman and Schwab (1985) in five different dimensions of satisfaction with pay such as level, benefits, raises, structure, and administration. Internal reliability was generally acceptable ranging between .75 and .89 (e.g., satisfaction with pay and benefits (.89), supervisors (.83), coworkers (.78), and work (.75)). 


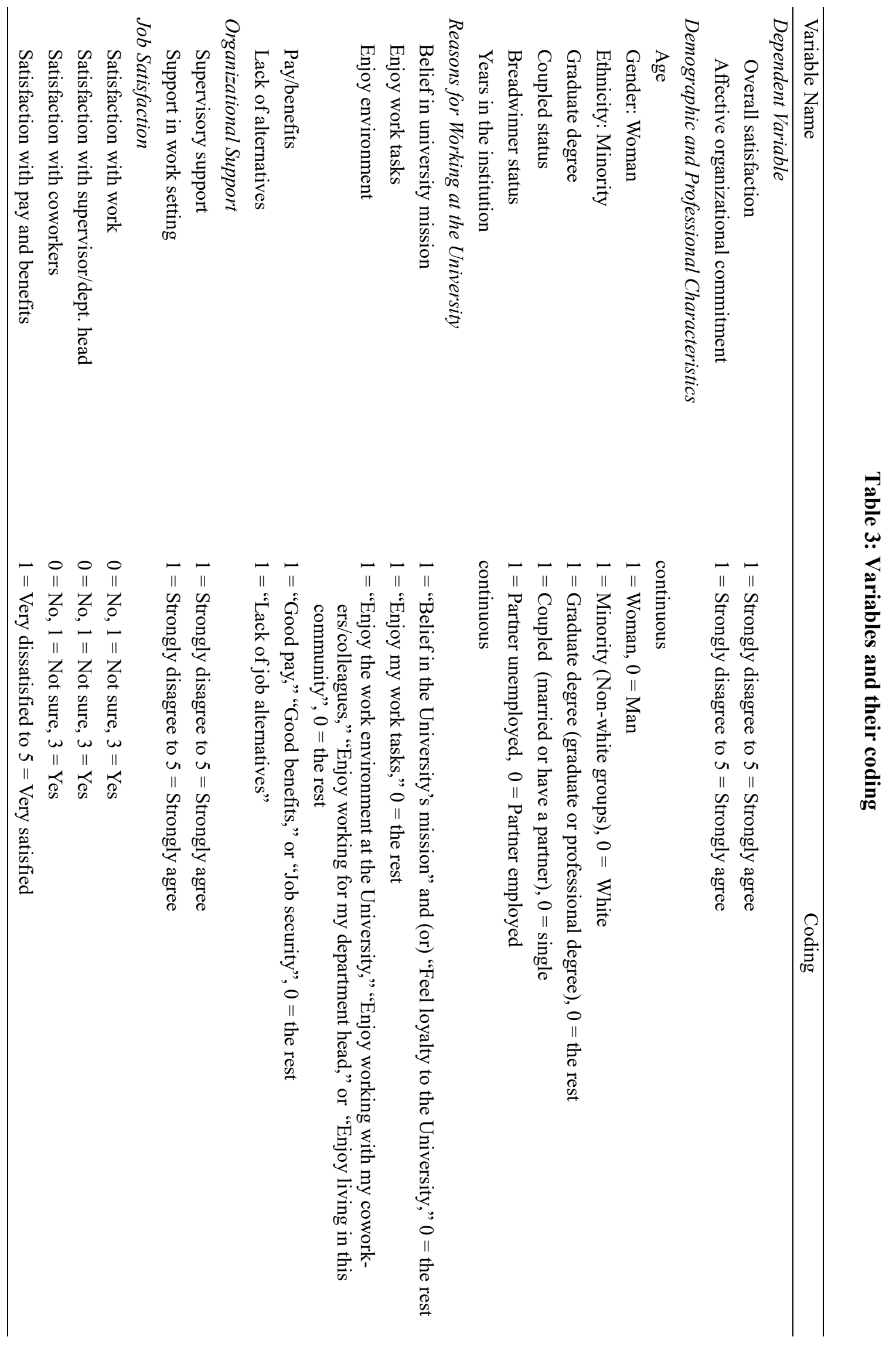


For dependent variables, one of the global satisfaction items ("Overall, I am satisfied with my employment at the university") was used for overall satisfaction. For organizational commitment, a question "If I were doing it again, I would accept a position at the University" was used to measure the extent to which an employee is affectively committed to an organization. Both overall satisfaction and affective organizational commitment were measured with a five-point scale where five is strongly agree to one is strongly disagree. Other demographic variables included are as follows (see Table 3): age, gender, ethnic background, graduate degree, couple status, breadwinner status (partner unemployed), years in the institution, and reasons for working at the university. Age and years in the institution were used as continuous variables in numbers. Gender was coded as a dummy variable $(1=$ women, $0=$ men $)$. All non-white ethnic groups were coded as minority (1) and the white as 0 . The graduate degree was also coded as holding graduate or professional degree (1) and the rest (0). Marital status was coded as coupled (married, same-sex domestic partner, living with a significant other or partner) (1) and the rest (0).

For breadwinner status, those who were coupled and had unemployed partner were coded as 1 and those whose partners were employed as 0 to identify sole income provider status. Reason for working at the university was coded under five subcategories (belief in university mission, enjoy work task, enjoy environment, pay/benefits, and lack of alternatives). Responses to more than one category were allowed in the original questionnaires, and each category was re-coded as a dummy variable $(1=$ yes, $0=$ no $)$.

\section{Student ratings of teaching}

Table 4 presents the statements in the SRT form that students answer in their evaluation of instructors and learning near the end of each semester. SRT is designed to measure students' perceptions of their instructors, in terms of their preparedness, presentation, feedback, and respectful attitudes, and their own assessment of learning and interest in the subject. They choose their answers from a score range of 1 (strongly disagree) to 6 (strongly agree). Every instructor, regardless of one's rank or title, is required to distribute this form in class and to submit responses to the department. SRT of contingent faculty are considered at a departmental level for continuation or dismissal of their contracts. In this study, SRT was used as a way of assessing the satisfaction of students for the teaching performed by contingent faculty and TTTF. Although SRT can be limited in indicating the quality of their teaching when used as a sole measure, it was used as a proxy of their teaching quality perceived by students.

Table 4: Student Ratings of Teaching (SRT) items

\begin{tabular}{lc}
\hline \multicolumn{1}{c}{ Statement in the SRT } & Scale \\
\hline The instructor was well prepared for class. & 1 Strongly disagree \\
The instructor presented the subject matter clearly. & 2 Disagree \\
The instructor provided feedback intended to improve my course performance. & 3 Somewhat disagree \\
The instructor treated me with respect. & 4 Somewhat agree \\
I have a deeper understanding of the subject matter as a result of this course. & 5 Agree \\
My interest in the subject matter was stimulated by this course. & 6 Strongly agree
\end{tabular}

\section{Procedures}

Correlation analyses were conducted for all variables (see Appendix A and B). Perception of department head's supervisory support was removed in the regression analyses to avoid multicollinearity. For both contingent faculty and TTTF, perception of department head's supervisory sup- 
port was highly correlated with both satisfaction with department head (contingent faculty: .71; TTTF: .74) and perception of support at work (contingent faculty: .68; TTTF: .69).

The collected SRT data were sorted by the size of class (e.g., under 10 students: small-size class, 10 to under 30: medium-size class, 30 to under 50: large-size class, and over 50 students: megasize class). When a teacher taught more than one class, classes were treated separately in order not to aggregate results from different class types or sizes. Mean was used to represent the result of each of the six items in SRT and was compared between contingent faculty and TTTF for groups of each size.

\section{Results}

In this section, comparisons of demographic variables and reasons for working at the university are presented as well as comparisons of workplace attitudes and perception of support at work between contingent faculty and TTTF. Results of regression analyses are presented next, followed by comparisons of SRT results in each class-size groups between two faculty groups. According to Table 5, there were statistically significant differences between contingent faculty and TTTF in some demographic characteristics as well as the reasons for working at the university. Whereas there were no statistically significant differences in the percentage of non-white ethnicity (contingent faculty: 15\%; TTTF: 19\%), breadwinner status (contingent faculty: 26\%; TTTF: 21\%), and age (contingent faculty: 48.4 years old; TTTF: 50.1 years old) between contingent faculty and TTTF, the percentage of women (contingent faculty: $57 \%$; TTTF: $41 \%, p<.001$ ) and the percentage of holding graduate degree (contingent faculty: 93\%; TTTF: $99 \%, p<.001$ ) and the years in the institution (contingent faculty: 9.7 years; TTTF: 15.4 years, $p<.001$ ) was statistically significantly lower for contingent faculty than TTTF. There were more people who were either married or had a partner among contingent faculty than among TTTF at a statistically significant level $(p<.001)$.

Table 5: Demographic variables and reasons for working at the university, contingent faculty vs. TTTF

\begin{tabular}{lccccc}
\hline & \multicolumn{5}{c}{ Group } \\
\cline { 2 - 5 } & \multicolumn{2}{c}{ Contingent } & Taculty & \multicolumn{2}{c}{ TTTF } \\
\cline { 2 - 5 } & Mean & SD & Mean & SD & \\
\hline Woman & .57 & .50 & .41 & .49 & $* * *$ \\
Minority & .15 & .36 & .19 & .39 & \\
Graduate degree & .93 & .26 & .99 & .11 & $* * *$ \\
Coupled & .92 & .28 & .81 & .39 & $* * *$ \\
Breadwinner & .26 & .44 & .21 & .41 & \\
Age & 48.4 & 11.3 & 50.1 & 10.9 & \\
Years in the institution & 9.7 & 7.7 & 15.4 & 11.6 & $* * *$ \\
The reason for working at university & & & & & \\
$\quad$ Belief in university mission & .30 & .46 & .49 & .50 & $* * *$ \\
Enjoy work tasks & .75 & .44 & .69 & .46 & \\
$\quad$ Enjoy work environment & .19 & .40 & .86 & .35 & $* * *$ \\
$\quad$ Pay/benefits & .37 & .48 & .66 & .47 & $* * *$ \\
$\quad$ Lack of alternatives & .23 & .42 & .15 & .35 & $* *$ \\
\hline
\end{tabular}

${ }^{*} p<0.05 * * p<0.01 * * * p<0.001$

1) Breadwinner: spouse or partner unemployed

2) Age and years in the institution: numbers in years 
To the question asking what the reason they work for university was, more TTTF answered that it was because of their belief in university's mission (contingent faculty: 30\%; TTTF: $49 \%, p$ $<.001$ ) and pay/benefits (contingent faculty: 37\%; TTTF: 66\%, $<.001$ ), and because they enjoy the work environment (contingent faculty: 19\%; TTTF: $86 \%, p<.001$ ) than contingent faculty at a statistically significant level. On the other hand, more contingent faculty answered that the reason they work at the university was because of the lack of alternatives (contingent faculty: $23 \%$;

TTTF: $15 \%, p<.01)$, than TTTF, at a statistically significant level. There was no statistically significant difference between contingent faculty and TTTF groups in the answer for if the reason they work at the university was because they enjoyed their work tasks. For both contingent faculty and TTTF, the majority of respondents answered that they work for the university because they enjoy their work (contingent faculty: 75\%; TTTF: 69\%).

According to Table 6, there were statistically significant differences in satisfaction with work and satisfaction with coworkers between contingent faculty and TTTF. The mean of satisfaction with work for contingent faculty (2.71) was slightly higher than TTTF $(2.43)(p<.001)$. Satisfaction with coworkers was also higher for contingent faculty (2.69) than TTTF $(2.31)(p<.001)$. Affective commitment (accept the position in the university if doing again) was also slightly higher for contingent faculty (4.18) than TTTF (4.00) at the .05 level. There was no statistically significant difference in satisfaction with dept. head, satisfaction with pay/benefits, and overall satisfaction between contingent faculty and TTTF. According to Table 7, the level of contingent faculty's perception of being supported at work (3.88) was statistically significantly higher than TTTF (3.68) $(p<.01)$ There was no difference in the perception of supervisory support between contingent faculty and TTTF at a statistically significant level.

Table 6: Workplace attitudes, contingent faculty vs. TTTF

\begin{tabular}{lccccc}
\hline & \multicolumn{5}{c}{ Group } \\
\cline { 2 - 5 } & \multicolumn{2}{c}{ Contingent Faculty } & \multicolumn{2}{c}{ TTTF } & \multirow{2}{*}{ t- } \\
\cline { 2 - 5 } & Mean & SD & Mean & SD & $* * *$ \\
\hline Satisfaction with work & 2.71 & 0.58 & 2.43 & 0.60 & $*$ \\
Satisfaction with dept. head & 2.36 & 0.82 & 2.37 & 0.88 & \\
Satisfaction with coworkers & 2.69 & 0.62 & 2.31 & 0.67 & $* * *$ \\
Satisfaction with pay/benefits & 2.90 & 0.74 & 3.02 & 0.82 & \\
Overall satisfaction & 3.93 & 1.00 & 3.94 & 1.07 & \\
Affective commitment & 4.18 & 0.92 & 4.00 & 1.08 & $*$ \\
\hline
\end{tabular}

$* p<0.05 * * p<0.01 * * * p<0.001$

Note: Satisfaction with work, dept. head, coworkers scale range: 0-3

Satisfaction with pay/benefits, overall satisfaction, and affective commitment scale range: $1-5$

Table 7: Perception of organizational support, contingent faculty vs. TTTF

\begin{tabular}{llllll}
\hline & \multicolumn{5}{c}{ Group } \\
\cline { 2 - 5 } & \multicolumn{2}{c}{ Contingent Faculty } & TTTF & t- \\
\cline { 2 - 5 } & Mean & SD & Mean & SD & \\
\hline Perception of being supported at work & 3.88 & 0.80 & 3.68 & 0.93 & $*$ \\
Perception of supervisory support & 3.49 & 1.01 & 3.62 & 1.02 & \\
\hline
\end{tabular}

${ }^{*} p<0.05 * * p<0.01 * * * p<0.001$

Note: Scale range: $1-5$ 
According to regression analyses results presented in Table 8, the two variables that most significantly predict overall satisfaction and affective organizational commitment of contingent faculty were satisfaction with pay and benefits (overall satisfaction: $\beta=.38, p<.001$; organizational commitment: $\beta=.29 . p<.001$ ) and perception of support at work (overall satisfaction: $\beta=.29, p$ $<.001$; organizational commitment: $\beta=.36, p<.001$ ). Following these two variables, when the reason for working at university was the lack of job alternatives, it was negatively related to the overall satisfaction of contingent faculty $(\beta=-.14, p<.05)$. When the reason for working at the university was enjoying work environment (relationship with supervisor, colleagues, and etc.), it was also negatively related to the affective organizational commitment of contingent faculty $(\beta=$ $-.13, p<.05)$. Satisfaction with work was also statistically significant in predicting the overall satisfaction $(\beta=.14, p<.05)$ and affective organizational commitment of contingent faculty $(\beta$ $=.13, p<.05)$.

For TTTF, perception of support at work was the strongest predictor in explaining both overall satisfaction $(\beta=.33, p<.001)$ and affective organizational commitment $(\beta=.39, p<.001)$. Whether the reason for working at university was enjoyment of work tasks or not was the next strongest predictor for both dependent variables (overall satisfaction: $\beta=.20, p<.001$; affective organizational commitment: $\beta=.17, p<.01$ ). When a TTTF member was working at the university because of the lack of other alternatives, it was negatively related to both overall satisfaction $(\beta=-.10, p<.05)$ and affective organizational commitment $(\beta=-.16, p<.01)$. Satisfactions with work $(\beta=.18, p<.01)$, pay and benefits $(\beta=.18, p<.01)$, and department head $(\beta=.16, p$

$<.05)$ were positively related to the overall satisfaction of TTTF. 


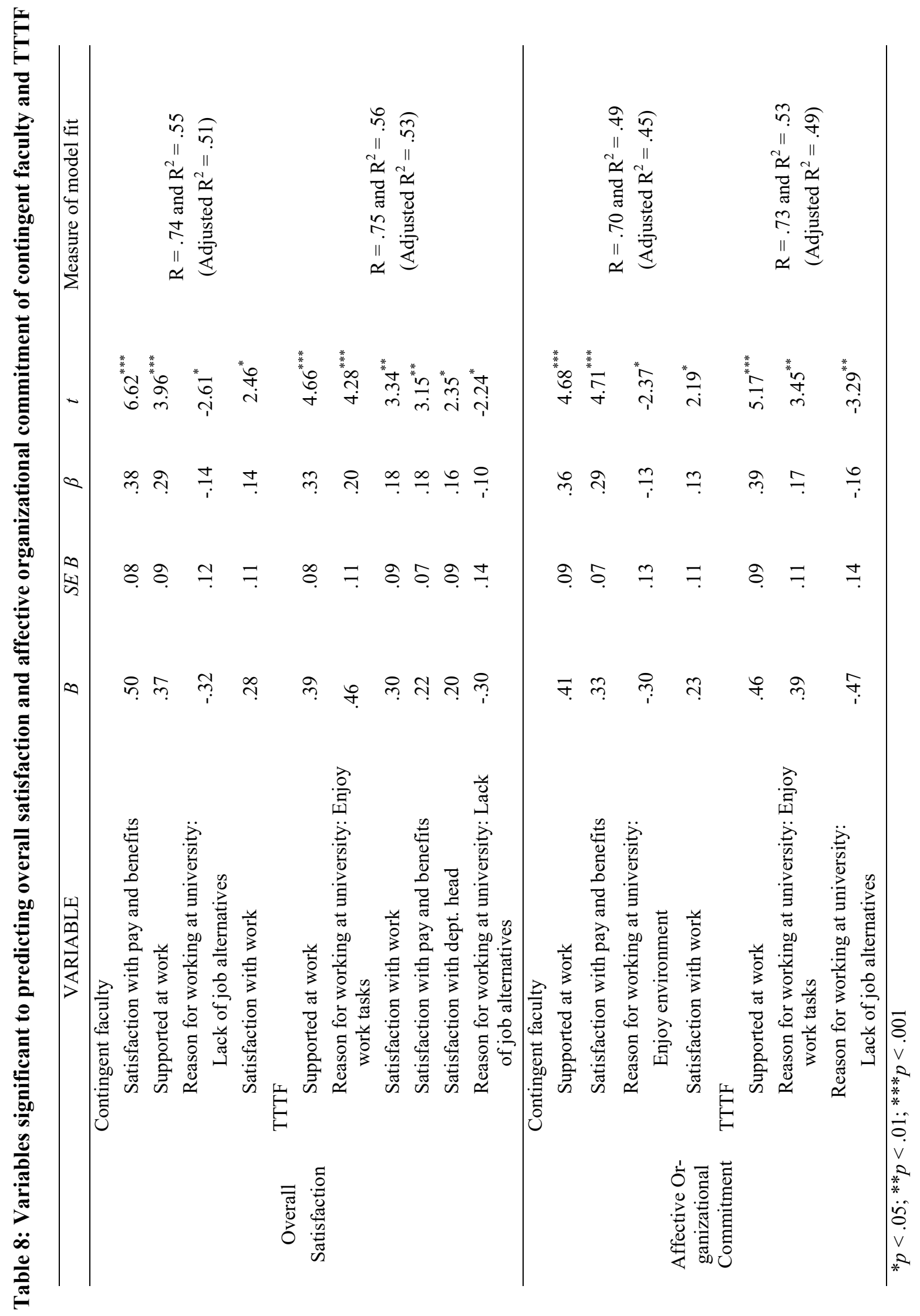


Results presented in Table 9 through 12 suggest that students were generally satisfied with the instruction by both contingent faculty and TTTF. Averages for each size group were all over five when six was the highest. Whereas there were few statistically significant differences in small (less than ten students) and mega-size (over 50 students) classes between contingent faculty and TTTF, SRT means for contingent faculty were slightly higher than TTTF, at statistically significant levels, in medium (10-30 students) and large-size (30-50 students) classes. Although there were few mean differences in small-size classes, TTTF had a slightly higher mean in 'respectful attitude' (TTTF: 5.75; contingent faculty: 5.66) at a statistically significant level $(p<.05)$ (see Table 9).

Table 9: SRT results for small-size classes, contingent faculty vs. TTTF

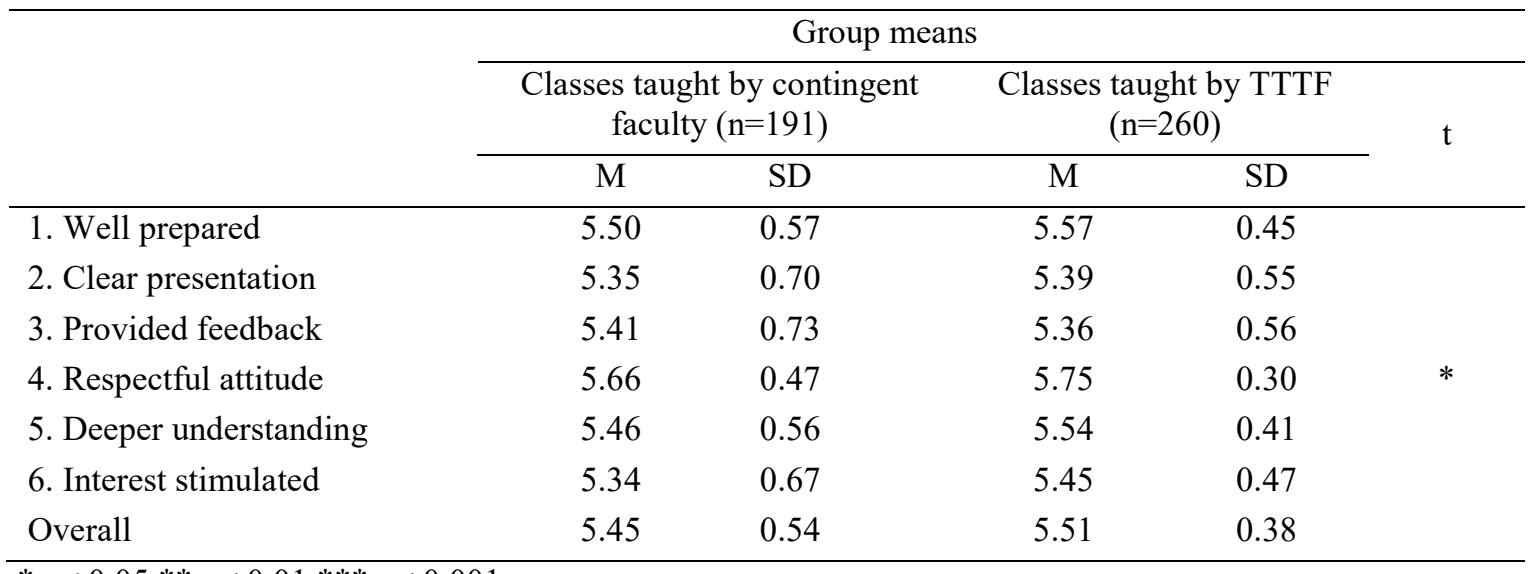

${ }^{*} p<0.05 * * p<0.01 * * * p<0.001$

Note: Scale range: 1-6

According to Table 10, SRT means for contingent faculty were all higher, at a statistically significant level, than TTTF in medium-size (10-30 students) classes. Means were higher in 'clear presentation' (contingent faculty: 5.38; TTTF: 5.18 ) and 'provided feedback intended to improve my course performance' (contingent faculty: 5.37; TTTF: 5.11) at a significant level $(p<.001)$. The means were also slightly higher for 'well prepared' (contingent faculty: 5.59; TTTF: 5.50), 'I have a deeper understanding of the subject matter as a result of this course' (contingent faculty: 5.42; TTTF: 5.28), 'interest stimulated' (contingent faculty: 5.19; TTTF: 5.09) $(p<.01)$, and 'respectful attitudes' (contingent faculty: 5.65; TTTF: 5.59) $(p<.05)$.

Table 10: SRT results for medium-size classes, contingent faculty vs. TTTF

\begin{tabular}{lccccc}
\hline & \multicolumn{5}{c}{ Group means } \\
\cline { 2 - 5 } & \multicolumn{2}{c}{$\begin{array}{c}\text { Classes taught by contin- } \\
\text { gent faculty }(\mathrm{n}=855)\end{array}$} & \multicolumn{2}{c}{$\begin{array}{c}\text { Classes taught by TTTF } \\
(\mathrm{n}=409)\end{array}$} & $\mathrm{M}$ \\
\cline { 2 - 5 } & $\mathrm{M}$ & $\mathrm{SD}$ & 5.50 & 0.47 & $* *$ \\
\hline 1. Well prepared & 5.59 & 0.41 & 5.18 & 0.65 & $* * *$ \\
2. Clear presentation & 5.38 & 0.51 & 5.11 & 0.60 & $* * *$ \\
3. Provided feedback & 5.37 & 0.51 & 5.59 & 0.40 & $*$ \\
4. Respectful attitude & 5.65 & 0.35 & 5.28 & 0.56 & $* *$ \\
5. Deeper understanding & 5.42 & 0.46 & 5.09 & 0.64 & $* *$ \\
6. Interest stimulated & 5.19 & 0.56 & 5.29 & 0.51 & $* * *$ \\
Overall & 5.43 & 0.42 & & & $*$ \\
\hline
\end{tabular}

${ }^{*} p<0.05 * * p<0.01 * * * p<0.001$

Note: Scale range: 1-6 
For large-size classes (30-50 students) (see Table 11), SRT means were also higher at a statistically significant level for contingent faculty than TTTF in 'provided feedback intended to improve my course performance' (contingent faculty: 5.21; TTTF: 4.97) $(p<.001)$, 'clear presentation' (contingent faculty: 5.38; TTTF: 5.16) $(p<.01)$, 'deeper understanding' (contingent faculty: 5.38; TTTF: 5.24) and 'interest stimulated' (contingent faculty: 5.16; TTTF: 5.00) $(p<.05)$. According to Table 12, there was no statistically significant difference in SRT means between contingent faculty and TTTF in mega-size (over 50 students) classes.

Table 11: SRT results for large-size classes, contingent faculty vs. TTTF

\begin{tabular}{lccccc}
\hline & \multicolumn{5}{c}{ Group means } \\
\cline { 2 - 5 } & $\begin{array}{c}\text { Classes taught by contin- } \\
\text { gent faculty }(\mathrm{n}=165)\end{array}$ & $\begin{array}{c}\text { Classes taught by TTTF } \\
(\mathrm{n}=101)\end{array}$ & \multirow{2}{*}{$\mathrm{t}$} \\
\cline { 1 - 5 } & $\mathrm{M}$ & $\mathrm{SD}$ & $\mathrm{M}$ & $\mathrm{SD}$ & \\
\hline 1. Well prepared & 5.60 & 0.38 & 5.56 & 0.33 & \\
2. Clear presentation & 5.38 & 0.45 & 5.16 & 0.55 & $* * *$ \\
3. Provided feedback & 5.21 & 0.45 & 4.97 & 0.47 & $* * *$ \\
4. Respectful attitude & 5.57 & 0.38 & 5.56 & 0.35 & \\
5. Deeper understanding & 5.38 & 0.45 & 5.24 & 0.47 & $*$ \\
6. Interest stimulated & 5.16 & 0.55 & 5.00 & 0.56 & $*$ \\
Overall & 5.38 & 0.40 & 5.25 & 0.41 & $* *$ \\
\hline \multicolumn{1}{c}{$* p<0.05 * * p<0.01 * * * p<0.001$} & & & &
\end{tabular}

Note: Scale range: $1-6$

Table 12: SRT results for mega-size classes, contingent faculty vs. TTTF

\begin{tabular}{lcccc}
\hline & \multicolumn{4}{c}{ Group means } \\
\cline { 2 - 5 } & $\begin{array}{c}\text { Classes taught by contingent } \\
\text { faculty }(\mathrm{n}=116)\end{array}$ & $\begin{array}{c}\text { Classes taught by TTTF } \\
(\mathrm{n}=94)\end{array}$ & $\mathrm{t}$ \\
\cline { 2 - 5 } & $\mathrm{M}$ & $\mathrm{SD}$ & $\mathrm{M}$ & $\mathrm{SD}$ \\
\hline 1. Well prepared & 5.59 & 0.27 & 5.54 & 0.42 \\
2. Clear presentation & 5.21 & 0.45 & 5.10 & 0.66 \\
3. Provided feedback & 4.93 & 0.50 & 4.85 & 0.54 \\
4. Respectful attitude & 5.50 & 0.44 & 5.50 & 0.32 \\
5. Deeper understanding & 5.23 & 0.38 & 5.15 & 0.53 \\
6. Interest stimulated & 4.87 & 0.54 & 4.81 & 0.63 \\
Overall & 5.22 & 0.39 & 5.16 & 0.49 \\
\hline
\end{tabular}

$* p<0.05 * * p<0.01 * * * p<0.001$

Note: Scale range: 1-6

\section{Conclusion}

The results of this study indicate that contingent faculty at this particular university were not only satisfied with their work and their relationships with coworkers but also feel supported at their workplace at a comparable level to TTTF. Since the contingent faculty in this study all had appointments at 50 percent or higher, they may have experienced more stability than individuals with lower percentage of time appointments. Nevertheless, these results suggest an important piece of information in understanding contingent faculty in a public research university. 
For example, they are excellent teachers. In this study, contingent faculty were viewed by students being as competent as TTTF in their teaching, especially in medium (10-30 students) and large-size (30-50 students) classes. There was no noticeable and statistically significant difference in SRT between contingent faculty and TTTF in small (less than 10 students) and mega-size (over 50 students) classes. However, within medium-size classes, contingent faculty did have higher SRT mean results than TTTF in all areas of SRT items. Within large-size classes, they had higher means in 'class presentation,' 'feedback,' 'deeper understanding,' and 'interest stimulated' than TTTF. These results not only refute the misconception that contingent faculty have too little time to provide students with feedback but also support that they provide students with teaching which is as good as that provided by TTTF, at least in medium-size and large-size classes. In line with such result, a study by Figlio et al. (2013, September 1) in a private research university also found that students who were average or less-qualified learned relatively more in their introductory courses from contingent faculty across a wide variety of subject areas.

In the case of the institution where our study was done-given the workplace attitudes, perception of support at work, and their students' ratings of teaching found in the study - the employment relationship of contingent faculty was quite stable and indicated that it is closer to a combined economic and social exchange model than to a pure economic exchange model or underinvestment model (see Table 1). Contingent faculty members' perception of being supported at work and the level of affective organizational commitment were not any lower than TTTF; satisfaction with work and coworkers was also higher. Given that their SRT results supported that they are providing excellent teaching, especially in medium to large-size classes in lower division undergraduate courses, contingent faculty members are performing quite successfully in their contribution to the teaching missions of their institution. A case study on the historical development of contingent faculty in this particular institution also supports that contingent faculty have grown, over time, as essential partners for institutional missions, which was made possible due to the efforts of administrators and faculty involved (Tkachenko \& Seashore, 2013, Nov).

As presented in the types of employee-organization relationship (Tsui et al., 1997), a combined economic and social exchange model is a more balanced approach that entails both parties' efforts. It is based not only on economic reasons for flexibility but also on the mutual investment of each party so that employees can perform roles that are necessary for the benefits of their institutions even when they were not mandated by their contracts. Since teaching is a position that easily requires expandable work roles that are based on trust and go beyond explicit description in contracts, it is conceivable that contingent faculty, whose job is primarily teaching, will appreciate support from their institution that are expressed in ways such as more stable types of contracts and recognition of their contributions and perform even better. This study has found that, in a public research university, contingent faculty can have a satisfying worklife - although not perfect - feel that they are valued by their institution, and be excellent teachers.

\section{Recommendations}

Although the tenure system has been central to the development of the status of TTTF and governance in academia, it is increasingly important to establish equivalent rewards and promotional systems for contingent teaching faculty in terms of titles and categorization, as well as resources. As found in this study, keeping a comparable level of pay is also important. Their satisfaction with pay/benefits was one of the strongest predictors in workplace attitudes. To help attract and retain competent teaching faculty and staff, institutions need to signal that they are paying attention to this group by providing intentional efforts and policies.

Including contingent faculty in the institutional data systems and tracking changes is another way to help this group flourish. Because no systematic management of contingent faculty data has been routinely accomplished in major public research universities (Cross \& Goldenberg, 2009), 
more rigorous collection and the use of such data are recommended for the institutions that have a growing presence of contingent faculty group. For example, SRT has not been often used in understanding performance of contingent faculty as a group, although the SRT data can provide much needed information about contingent faculty members' teaching - as perceived by their students - at an institutional level. When used with other existing data sets in a complementary way, SRT data can be useful (Theall \& Franklin, 2001). Few research-intensive universities have, however, attempted using student-oriented teaching data for following up teaching performance across the types of teaching staff (Cross \& Goldenberg, 2009) when monitoring of students' evaluation of teaching could suggest some dependable guidance for acknowledging and supporting contingent faculty's teaching.

Lastly, students of higher education should be informed that faculty members' employment relationships with their institutions are no longer homogenous. Organizations should be advised to pay closer attention to various perceptions and demands resulting from increasingly diversified forms of employment contracts. No longer are all instructional personnel expected to perform the traditional tripartite roles of research, teaching, and service in the same manner or proportions. The implications of this study suggest that the extent to which contingent faculty members perceive their institution as being supportive is related to their workplace attitudes and their performance. The more support contingent faculty perceive, the more satisfied, committed, and high performing they will be. This simple principle of social exchange theory indicates that contingent faculty's roles and contributions would also need to be formally acknowledged and supported if their institutions expect from these individuals their best performance.

\section{Limitations}

The limitations of this study are largely based on the scope of participants and the nature of the survey instrument used. Because the survey was originally administered to all faculty and staff with appointments of at least 50 percent FTE, those who worked less than that were not included. Since many contingent faculty around the country work less than 50 percent, it is not known whether their attitudes and responses would have been similar or different from those included in this study. The scope of the application of this study's results may be thus limited.

Another limitation involves the survey items tapping Perceived Organizational Support (POS). The original POS items that exactly match the original Survey of Perceived Organizational Support (SPOS) (R. Eisenberger et al., 1986) were not used, and the interpretation of POS may not be completely transferrable to the survey items used in this study. Nevertheless, the alternative items used in this study regarding employees' perception of support from their workplace were internally reliable (.94) and could be used as a proxy to represent the level of perception of support from organizations.

Lastly, this study was conducted in a public, land-grant research institution located in the Midwest. Although other public research universities may share many similar context factors or features, the history of employment and academic cultures are unique to this one institution. A direct transfer of this study's results and implications may not be warranted to other institutions.

\section{Suggestions for Future Research}

For future research, a more in-depth investigation of the teaching strategies of contingent faculty would contribute to understanding how they address some difficulties they face in the classrooms. Although their teaching in medium or large size classes were found to be done in a comparably excellent level, in this study, what they find as barriers for better teaching could inform continued support for this group. Observation of classrooms would be also help understanding any different strategies or approach made in different sizes of classroom settings. 
In this study, term faculty and instructional staff were aggregated as one contingent faculty group to attain enough sample size to represent population. However, examining how similar or disparate characteristics these two groups have could help each college address more specific needs for supporting their contingent faculty group. For example, in health science, including medicine, the use of term faculty is more prevalent than in other colleges. The use of professorial title, although it is not accompanied with eligibility for tenure, is preferred in some disciplines. Instructional staff is, on the other hand, more commonly used in liberal arts. Such discipline-specific trends in the recruitment and employment of contingent faculty need to be identified at the unit level for better monitoring. Lastly, although the primary focus of this study was comparative examination between contingent faculty and TTTF as aggregate groups, further analyses of contingent faculty subgroups such as faculty of color or women contingent faculty members would help higher education institutions to be better informed about the implications of the increase of these subgroups among contingent faculty.

\section{Concluding Remarks}

With changing environments and increased pressures for funding, public research universities are undergoing transformations. As one of these changes, contract-based teaching faculty are increasingly taking part in fulfilling the educational mission of these institutions. Such change in the status of professorial positions in universities is also a part of a global trend (Kuzminov, 2012).

Internationally, contracts and fixed-term appointments are more common employment practices in academia than before, yet there are also some variations in how each country's academia responds to the trend. Western Europe is relatively less affected by this trend although the number of their non-tenure employment is also growing (Altbach, Reisberg, \& Pacheco, 2012). In Canada, where employment practices are highly decentralized in each province, both full-time and part-time faculty are mostly unionized although the same level of benefits and pays are often not secured for part-time or non-tenure-track faculty (Jones \& Weinrib, 2012). In Mexico, according to Altbach et al. (2012), part-time academic staff members are eligible for tenure as well as fulltime, and part-time academic staff in Argentina are paid on a comparable level with full-time staff.

It is undeniable that the growth of faculty groups who specialize in teaching under contracts, although they have been less acknowledged than TTTF, have allowed institutions to more flexibly deal with volatile circumstances (Kuzminov, 2012). There needs to be an awareness to help this group thrive in academia, even under the employment patterns of contracts, in a way that is mutually beneficial and building trusts of both parties. Organizational practices and culture of academic institutions need to adjust to this change in a way that better addresses the needs of their more diverse faculty group.

The former president of the university where this current study was based suggested that a "hybrid" public research university will be more commonly seen in the twenty-first century as a response to the needs of students than those of the state (Yudof, 2003). Shrinking state support primarily explains this change. Keeping these institutions flourishing will not be an easy task with this major political change, although they will try to remain a vital learning institution by supporting the traditional values such as access, dissemination of knowledge, and promotion of public good. This explains the urgency of understanding and supporting an increasingly significant part of the workforce in academia--contingent faculty. Such faculty will play an even more important role in carrying out institutional missions and communicating institutional values. How institutions support this group, for their successful fulfillment of mission, will be critical for their future. 


\section{References}

Abrami, P. C., d'Apollonia, S., \& Cohen, P. A. (1990). The validity of student ratings of instruction: What we know and what we don't. Journal of Educational Psychology, 82, 219-231.

Abrami, P. C., Theall, M., \& Mets, L. A. (2001). Editors' notes. New Directions for Institutional Research, 2001(109), 1-6. doi: 10.1002/ir.15

Altbach, P. G. (2005). Harsh realities: The professoriate faces a new century. In P. G. Altbach, R. O. Berdahl. \& P. J. Gumport (Eds.), American higher education in the twenty-first century: Social, political, and economic challenges (2nd ed.). Baltimore, MD: The Johns Hopkins University Press.

Altbach, P. G., Reisberg, L., \& Pacheco, I. (2012). Academic remuneration and contracts: Global trends and realities. In P. G. Altbach, L. Reisberg, G. Yudkevich, G. Androushchak \& I. Pacheco (Eds.), Paying the professoriate: A global comparison of compensation and contracts (pp. 3-20). New York, NY: Routledge.

Ambrose, S., Huston, T., \& Norman, M. (2005). A qualitative method for assessing faculty satisfaction. Research in Higher Edcuation, 46(7), 803-830.

Aselage, J., \& Eisenberger, R. (2003). Perceived organizational support and psychological contracts: A theoretical integration. Journal of Organizational Behavior, 24(5), 491-509. doi: 10.2307/4093703

Baldwin, R. G., \& Chronister, J. L. (2001). Teaching without tenure: Policies and practices for a new era. Maryland, Baltimore: The Johns Hopkins University Press.

Baldwin, R. G., \& Wawrzynski, M. R. (2011). Contingent faculty as teachers: What we know; what we need to know. American Behavioral Scientist, 55(11), 1485-1509.

Bataille, G. M., \& Brown, B. E. (2006). Faculty career paths: Multiple routes to academic success and satisfaction. Westpoint, CT: Praeger Publishers.

Bland, C. J., Center, B. A., Finstad, D. A., Risbey, K. R., \& Staples, J. (2006). The impact of appointment type on the productivity and commitment of full-time faculty in research and doctoral institutions. The Journal of Higher Education, 77(1), 89-123.

Blau, P. M. (1964). Exchange and power in social life. New York, NY: Wiley \& Sons.

Brint, S. (2006). Can public research universities compete? Research and Occasional Papers Series: CSHE.17.06. Retrieved from http://escholarship.org/uc/item/7pb373fw

Brubacher, J. S., \& Rudy, W. (1997). Higher education in transition. Piscataway, NJ: Transaction Publishers.

Cameron, K. (1978). Measuring organizational effectiveness in institutions of higher education. Administrative Science Quarterly, 23(4), 604-632.

Carrier, C., \& Wilhelmson, N. (2013). Recent experience of one university's journey to a more robust staffing model for instructional roles. Unpublished manuscript. University of Minnesota. Minneapolis, MN.

Cherrington, D. J., Reitz, H. J., \& Scott, W. E. (1971). Effects of contingent and noncontingent reward on the relationship between satisfaction and task performance. Journal of Applied Psychology, 55(6), 531536.

Cohen, P. A. (1981). Student ratings of instruction and student achievement: A meta-analysis of multi section validity studies. Review of Eduational Research, 51(3), 287-309.

Cohen, P. A. (1987). A critical analysis and reanalysis of the multisection validity meta-analysis. Paper presented at the the annual meeting of the American Educational Research Association, Washington, DC.

CommitteeOnUndergraduateTeaching. (1968). The importance of teaching: A memorandum to the new college teacher report. New Haven, CT: Hazen Foundation. 
Connelly, C. E., \& Gallagher, D. G. (2004). Emerging trends in contingent work research. Journal of Management, 30(6), 959-983.

Cox, B. E., McIntosh, K. L., Terenzini, P. T., Reason, R. D., \& Quaye, B. R. L. (2010). Pedagogical signals of faculty approachability: Factors shapring faculty-student interaction outside the classroom. Research in Higher Edcuation, 51, 767-788.

Coyle-Shapiro, J., \& Kessler, I. (2000). Consequences of the psychological contract for the employment relationship: A large scale survey. Journal of Management Studies, 37(7), 903-930.

Coyle-Shapiro, J., \& Kessler, I. (2002). Contingent and non-contingent working in local government: Contrasting psychological contracts. Public Administration, 80(1), 77-101.

Cross, J. G., \& Goldenberg, E. N. (2009). Off-track profs. Cambridge, MA: The MIT Press.

d'Apollonia, S., \& Abrami, P. C. (1997). Navigating student ratings of instruction. American Psychologist, 52, 1198-1208.

Eagan, M. K., \& Jaeger, A. J. (2009). Effects of exposure to part-time faculty on community college transfer. Research in Higher Edcuation, 50, 168-188.

Eagan, M. K., \& Jaeger, A. J. (Eds.). (2008). Closing the gate: Part-time faculty instruction in gatekeeper courses and first-year persistence. San Francisco, CA: Jossey-Bass.

Eagan, M. K., Jaeger, A. J., \& Grantham, A. (2015). Supporting the academic majority: Policies and practices related to part-time faculty's job satisfaction. The Journal of Higher Education, 86(3), 448483.

Eberhardt, B. C., \& Shani, A. B. (1984). The effects of full-time versus part-time employment status on attitudes toward specific organizational chracteristics and overall job satisfaction. Academy of Management Journal, 27, 893-900.

Ehrenberg, R. G. (2010, October 1). Rethinking the professoriate. [Working Papers], Paper 117. Retrieved from http://digitalcommons.ilr.cornell.edu/workingpapers/117

Ehrenberg, R. G., \& Zhang, L. (2005). Do tenured and tenure-track faculty matter? The Journal of Human Resources, 40(3), 647-659.

Eisenberger, R., Huntington, R., Hutchison, S., \& Sowa, D. (1986). Perceived organizational support. Journal of Applied Psychology, 71(3), 500-507.

Eisenberger, R., Jones, J. R., Aselage, J., \& Sucharski, I. L. (2004). Perceived organizational support. New York, NY: Oxford University Press.

El-Khawas, E. (1992). Campus trends (No.82) Higher Education Panel Report. . Washington, DC: American Council on Education.

Feldman, D. C., \& Turnley, W. H. (2001). A field study of adjunct faculty: The impact of career stage on reactions to non-tenure-track jobs. Journal of Career Development, 28(1), 1-16.

Feldman, K. A. (1978). Course characteristics and college students' ratings of their teachers: What we know and what we don't. Research in Higher Education, 9(3), 199-242.

Feldman, K. A. (1988). Effective college teaching from the students' and faculty's view: Matched or mismatched priorities? Research in Higher Education, 28(4), 291-344.

Figlio, D. N., Schapiro, M. O., \& Soter, K. B. (2013, September 1). Are tenure track professors better teachers? NBER Working Paper Series. Retrieved from http://www.nber.org/papers/w19406

Gappa, J. M., \& Leslie, D. W. (1993). The invisible faculty. San Francisco: CA: Jossey-Bass.

Goodhartz, A. S. (1948). Student attitudes and opinions relating to teaching at Brooklyn College. School and Society, 68, 345-349. 
Greenhaus, J. H., Parasuraman, S., \& Wormley, W. M. (1990). Effects of race on organizational experiences, job performance evaluations, and career outcomes. The Academy of Management Journal, 33(1), 64-86. doi: 10.2307/256352

Groves, D. L., Kahalas, H., \& Lamb, F. (1976). Planning satisfaction and productivity. Long Range Planning 9(4), 52-57.

Gumport, P. J. (1997). Public universities as academic workplaces. Daedalus, 126(4), 113-136.

Harper, E. P., Baldwin, R. G., Gansneder, B. G., \& Chronister, J. L. (2001). Full-time women faculty off the tenure track: Profile and practice. Review of Higher Education, 24(3), 237-257.

Hearn, J. C., Lewis, D. R., Kallsen, L., Holdsworth, J. M., \& Hones, L. M. (2006). "Incentives for managed growth": A case study of incentives-based planing and budgeting in a large public research university. The Jounral of Higher Education, 77(2), 286-316.

Heck, R. H., Johnsrud, L. K., \& Rosser, V. J. (2000). Administrative effectiveness in higher education: Improving assessment procedures. Research in Higher Edcuation, 41(6), 663-684.

Heneman, H. G., \& Schwab, D. P. (1985). Pay satisfaction: Its multidimensional nature and measurement. . International Journal of Psychology, 20, 129-141.

Hofman, J. M., Posteraro, C., \& Presz, H. A. (1994, May). Adult learners: Why were they successful? Lessons learned via an adult learner task force. Paper presented at the Adult Learner Task Force Conference, Columbia, SC.

Hulin, C. L. (1991). Adaptation, persistence, and commitment in organization. In M. D. Dunnette \& L. M. Hough (Eds.), Handbook of industrial and organizational psychology (2nd ed., Vol. 2, pp. 445-505). Palo Alto, CA: Consulting Psychology Press.

Jacoby, D. (2006). Effects of part-time faculty employment on community college graduation rates. The Journal of Higher Education, 77(6), 1081-1103.

Jaeger, A. J. (2008). Contingent faculty and student outcomes. Academe, 94(6), 42-43.

Jaeger, A. J., \& Eagan, M. K. (2011a). Examining retention and contingent faculty use in a state system of public higher education. Education Policy, 25(3), 507-537.

Jaeger, A. J., \& Eagan, M. K. (2011b). Navigating the transfer process: Analyzing the effects of part-time faculty exposure by academic program. American Behavioral Scientist, 55(11), 1510-1532.

Johnson, I. Y. (2011). Contingent instructors and student outcomes: An artifact or a fact? Research in Higher Edcuation, 52, 761-785.

Johnsrud, L. K., \& Rosser, V. J. (2002). Faculty members' morale and their intention to leave: A multilevel explanation. The Jounral of Higher Education, 73(4), 518-542.

Jones, G. A., \& Weinrib, J. (2012). The organization of academic work andfaculty remuneration at Canadian universities. . In P. G. Altbach, L. Reiserg, M. Yudkevich, G. Androushchak \& I. Pacheco (Eds.), Paying the professoriate: A global comparion of compensation and contracts (pp. 83-93). New York, NY: Routledge.

Kalleberg, A. L. (1977). Work values and job rewards: A theory of job satisfaction. American Sociological Review, 42(1), 124-143.

Katzell, R. A., Yankelovich, D., Fein, M., Ornati, O. A., \& Nash, A. (1975). Improving productivity and job satisfaction. Organizational Dynamics, 4(1), 69-80.

Kezar, A., \& Sam, C. (2011). Understanding non-tenure track faculty: New assumptions and theories for conceptualzing behavior. American Behavioral Scientist, 55(11), 1419-1442.

Kulik, J. A. (2001). Student ratings: Validity, utility, and controversy. New Directions for Institutional Research, 2001(109), 9-25. doi: 10.1002/ir.1 
Faculty Perceptions of Organizational Support, Workplace Attitudes, and Teaching Evaluations

Kuzminov, Y. (2012). Academic community and contracts: Modern challenges responses. In P. G. Altbach, L. Reiserg, M. Yudkevich, G. Androushchak \& I. Pacheco (Eds.), Paying the professoriate: A global comparison of compensation and contracts (pp. 331-339). New York, NY: Routledge.

Lee, J. J., Cheslock, J., Maldonado-Maldonado, A., \& Rhoades, G. (2005). Professors as knowledge workers in the new, global, economy. In J. C. Smart (Ed.), Higher education: Handbook of theory and research (Vol. XX, pp. 55-132). London, UK: Springer.

Liden, R. C., Wayne, S. J., Kraimer, M. L., \& Sparrowe, R. T. (2003). The dual commitments of contingent workers: An examination of contingents' commitment to the agency and the organization. Journal of Organizational Behavior, 24(5), 609-625.

Likert, R. (1961). New patterns of management. New York, NY: McGraw-Hill.

Likert, R. (1967). The human organization. New York, NY: McGraw-Hill.

Locke, E. A. (1969). What is job satisfaction? Organizational Behavior and Human Performance, 4, 309336.

March, J. G., \& Simon, H. A. (1993). Organizations (2nd ed.). Cambrdige, MA: Blackwell Publishers.

Marler, J. H., Barringer, M. W., \& Milkovich, G. T. (2002). Boundaryless and traditional contingent employees: Worlds apart. Journal of Organizational Behavior, 23, 425-453.

Marsh, H. (1984). Students' evaluation of university teaching: Dimensionality, reliability, validity, potential biases, and utility. Journal of Educational Psychology, 76(5), 707-754.

Marsh, H. (1987). Students' evaluations of university teaching. Research findings, methodological issues and directions for future research. International Journal of Educational Research, 11(3), 253-388.

Martin, T. W., \& Berry, K. J. (1969). The teaching-research dilemma: Its sources in the university setting. The Journal of Higher Education, 40(9), 691-703.

Mathieu, J. E., \& Zajac, D. M. (1990). A review and meta-analysis of the antecedents, correlates, and consequences of organizational commitment. Psychology Bulletin, 108(2), 171-194.

Mayo, E. (1963). The human problems of an industrial civilization. New York, NY: Viking Press.

McDonald, D. J., \& Makin, P. J. (2000). The psychological contract, organizational commitment and job satisfaction of temporary staff. Leadership \& Organizational Development Journal, 21, 84-91.

McGregor, D. (1960). The human side of enterprise. New York, NY: McGraw-Hill.

Meyer, J. P., \& Allen, N. J. (1984). Testing the "side-bet theory" of organizational commitment: Some methodological considerations. Journal of Applied Psychology, 69(3), 372-378.

Meyer, J. P., \& Allen, N. J. (1997). A three-component conceptualization of organizational commitment. Human Resource Management Review, 1, 61-89.

Meyer, J. P., \& Herscovitch, L. (2001). Commitment in the workplace toward a general model. Human Resource Management Review, 11, 299-326.

Mottaz, C. J. (1987). An analysis of the relationship between work satisfaction and organizational commitment. The Sociological Quarterly, 28(4), 541-558.

Mowday, R. T., Porter, W. L., \& Steers, R. M. (1982). Employee-organization linkages. New York, NY: Academic Press.

Mowday, R. T., \& Steers, R. M. (1979). The measurement of organizational commitment. Journal of Vocational Behavior, 14, 224-247.

Nelsen, W. C. (1983). Faculty who stay: Renewing our most important resource. In R. G. Baldwin \& R. T. Blackburn (Eds.), College faculty: Versatile human resources in a period of constraint (pp. 67-83).

San Francisco, CA: Jossey-Bass. 
Neumann, Y., \& Finaly-Neumann, E. (1990). The reward-support framework and faculty commmitment to their university. Research in Higher Edcuation, 31(1), 75-97.

Newfield, C. (2008). Unmaking the public university: The forty-year assault on the middle class. Cambridge, MA: Harvard University Press.

Olsen, D., Maple, S. A., \& Stage, F. K. (1995). Women and minority faculty job satisfaction: Professional role interests, professional satisfactions, and institutional fit. The Journal of Higher Education, 66(3), 267-293.

Pearce, J. L. (1993). Toward an organizational behavior of contract laborers: Their psychological involvement and effects on employee co-workers. The Academy of Management Journal, 36(5), 10821096.

Rachelle, B. (2005). Measuring university quality. The Review of Higher Education, 29(1), 1-21.

Remmers, H. H. (1930). The measurement of teaching-personality and its relation to the learning process. Education, 51, 27-35.

Remmers, H. H., \& Elliot, D. N. (1949). The Indiana college and univeristy staff-evaluation program. School and Society, 70, 168-171.

Rhoades, G. (1996). Reorganizing the faculty workforce for flexibility: Part-time professional labor. The Jounral of Higher Education, 67(6), 626-659.

Rhoades, G. (2006). The higher education we choose: A question of balance. The Review of Higher Education, 29, 381-404.

Rhoades, L., \& Eisenberger, R. (2002). Perceived organizational support: A review of the literature. Journal of Applied Psychology, 87(4), 698-714.

Riley, J. W., Ryan, B. F., \& Lifshitz, M. (1950). The student looks at his teacher. New Brunswick, NJ: Rutgers University Press.

Ronco, S., \& Cahill, J. (2006). Does it matter who's in the classroom? Effect of instructor type on student retention, achievement and satisfaction. Paper presented at the Association of Institutional Research, Tallahassee, FL.

Rosser, V. J. (2004). Faculty members' intentions to leave: A national study on their worklfie and satisfaction. Research in Higher Edcuation, 45(3), 285-309.

Schuster, J. H., \& Finkelstein, M. J. (2006). The American faculty: The restructuring of academic work and careers. Baltimore, MD: Johns Hopkins University Press.

Seifert, T. A., \& Umbach, P. D. (2008). The effects of faculty demographic characteristics and disciplinary context on dimensions of job satisfaction. Research in Higher Edcuation, 49, 357-381.

Seldin, P. (1984). Changing practices in faculty evaluation: A critical assessment and recommendations for improvement. San Francisco, CA: Jossey-Bass.

Seldin, P. (1988). Evaluating college teaching. New Directions for Teaching and Learning, 1988(33), 4756.

Seldin, P. (1993). How colleges evaluate professors: 1983 versus 1993. AAHE Bulletin, October 1993(12), 6-8.

Shore, L. M., \& Coyle-Shapiro, J. A. M. (2003). New developments in the employee-organization relationship. Journal of Organizational Behavior, 24(5), 443-450.

Smith, P. C., Kendall, L. M., \& Hulin, C. L. (1969). The measurement of satisfaction in work and retirement: A strategy for the study of attitudes. Chicago, IL: Rand McNally.

Steers, R. M. (1977). Organizational effectiveness: A behavioral view. Santa Monica, CA: Goodyear Publishing Company, Inc. 
Theall, M., \& Franklin, J. (2001). Looking for bias in all the wrong places: A search for truth or a witch hunt in student ratings of instruction? New Directions for Institutional Research, 2001(109), 45-56. doi: 10.1002/ir.3

Tkachenko, O., \& Seashore, K. (2013, Nov). Re-shaping the faculty: A case study of the emergence and development of "permanent-contingent" roles. Paper presented at The Association for the Study of Higher Education (ASHE), St. Louis, MO, USA.

Toutkoushian, R. K., \& Bellas, M. L. (2003). The effects of part-time employment and gender on faculty earnings and satisfaction: Evidence from the NSOPF:93. The Journal of Higher Education, 74(2), 172195.

Tsui, A. S., Pearce, J. L., Porter, L. W., \& Tripoli, A. M. (1997). Alternative approaches to the employeeorganization relationship: Does investment in employees pay off? The Academy of Management Journal, 40(5), 1089-1121.

Umbach, P. D. (2008, Nov). The effects of part-time faculty appointments on instructional techniques and commitment to teaching. Paper presented at the Annual Conference of the Association for the Study of Higher Education, Jacksonville, FL.

Umbach, P. D., \& Wawrzynski, M. R. (2005). Faculty do matter: The role of college faculty in student learning and engagement. Research in Higher Edcuation, 46(2), 153-177.

Van Dyne, L., \& Ang, S. (1998). Organizational citizenship behavior of contingent workers in Singapore. Academy of Management Journal, 41, 692-703.

Voorde, K., Veldhoven, M., \& Paauwe, J. (2009). Strategic climate and organizational productivity: The role of work satisfaction. Academy of Management Proceedings, 1-6.

Wanous, J. P. (1974). A causal-correlational analysis of the job satisfaction and performance relationship. Journal of Applied Psychology, 59(2), 139-144.

Wyatt-Nichol, H. (2007). Job perceptions of contingent and traditional faculty. Academic Exchange Quarterly, 11(2), 164-171.

Yudof, M. (2003). An epilogue: Whither the public research university. In D. R. Lewis \& J. Hearn (Eds.), The public research university (pp. 241-243). Lanham, MD: University Press of America. 


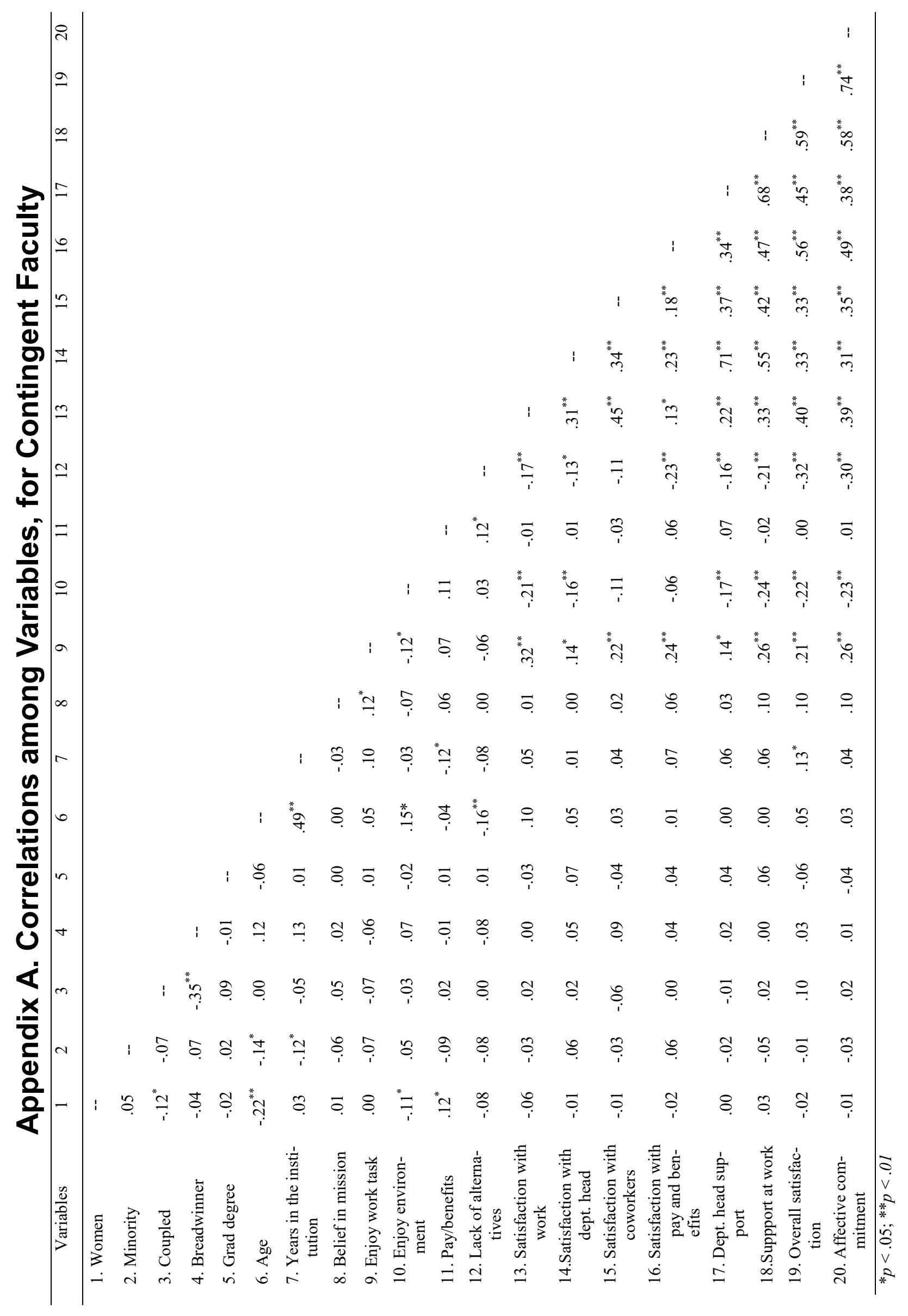




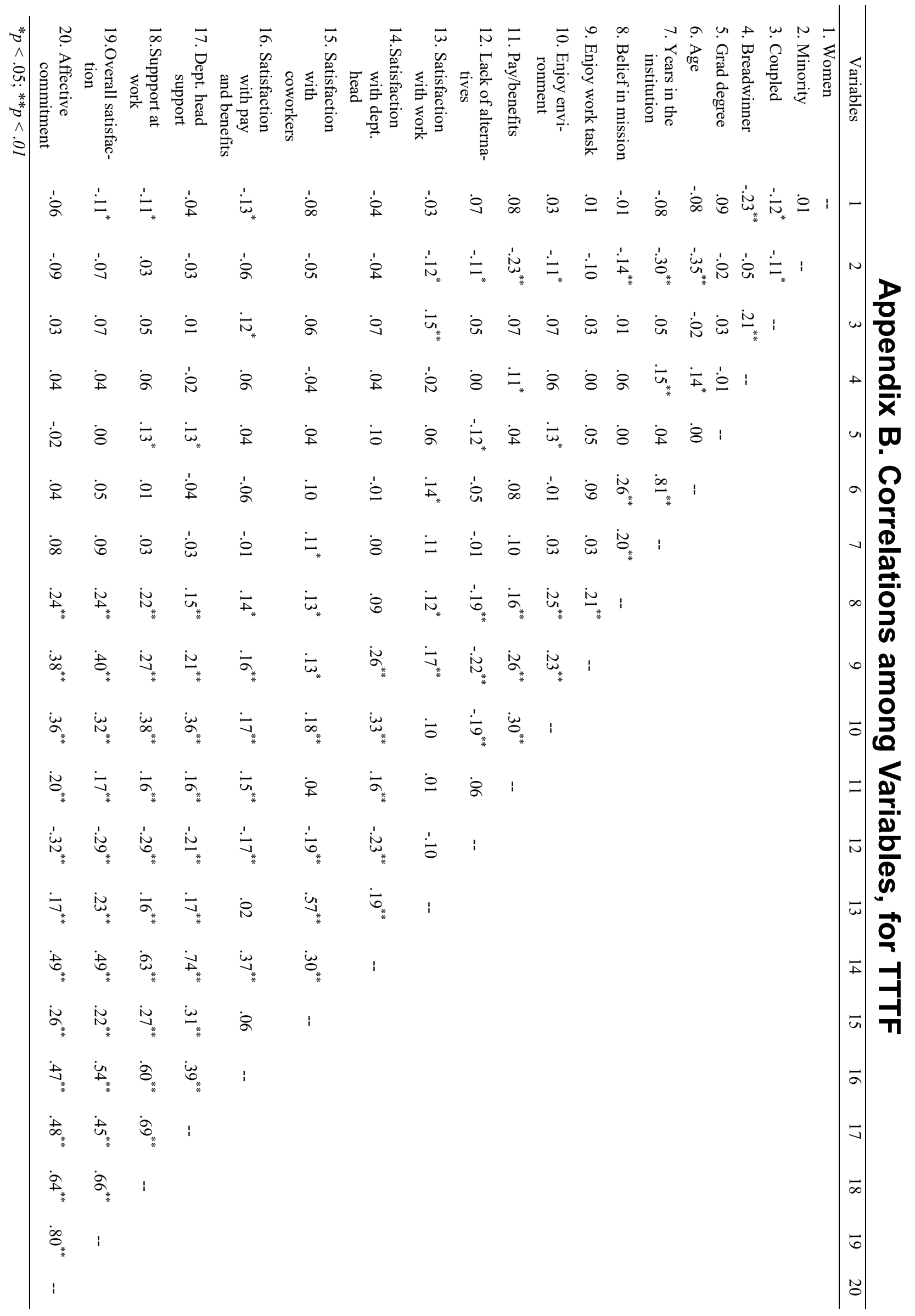




\section{Biographies}

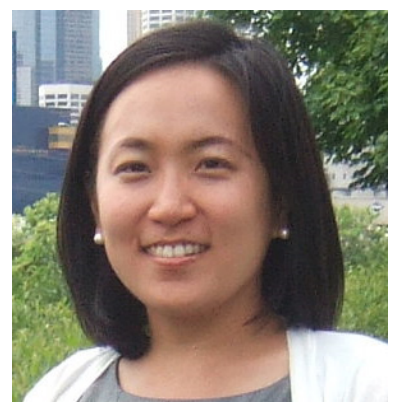

Min Young Cha works at Global Engagement Office in the Institute of Agriculture and Natural Resources (IANR), University of NebraskaLincoln. Originally from South Korea, she earned her Ph.D. in higher education at the University of Minnesota, Twin Cities, in 2015. She is interested in internationalization of higher education, faculty work, and Human Resources issues in higher education.

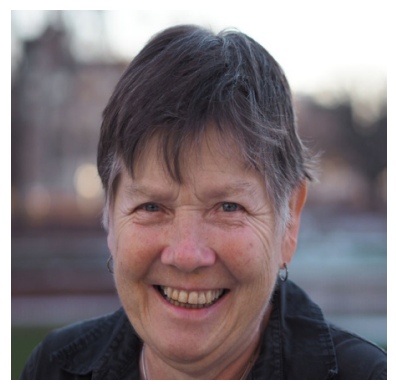

Carol Carrier, Professor, University of Minnesota, was the Vice President for Human Resources at the University of Minnesota for more than 20 years and now works in its Faculty Affairs office. In recent years, her research interests are in the different ways that research universities categorize academic staff and how salary equity issues are addressed. She earned her Ph.D. in instructional design at Syracuse University in 1976. 